\title{
The Influence of Inquiry Learning Model with Scaffolding on Cognitive Learning Outcomes in Biology Subjects of Eleventh Grade of Science Class in Special Region of Yogyakarta Mountain Areas
}

\author{
${ }^{1 s t}$ Aisyah Ferra Anggraini \\ Science Education, Postgraduate \\ Program, Faculty of Teacher \\ Training and Education \\ Universitas Sebelas Maret, \\ Indonesia \\ ichaferra@yahoo.com
}

\author{
${ }^{2 n d}$ Suciati Suciati \\ Science Education, Postgraduate \\ Program, Faculty of Teacher \\ Training and Education \\ Universitas Sebelas Maret, \\ Indonesia \\ suciatisudarisman@staff.uns.ac.id
}

\author{
${ }^{3 r d}$ Maridi Maridi \\ Science Education, Postgraduate \\ Program, Faculty of Teacher \\ Training and Education \\ Universitas Sebelas Maret \\ Indonesia \\ maridi_uns@yahoo.co.id
}

\begin{abstract}
Inquiry learning model model with scaffolding is a combination of inquiry learning model with scaffolding. Scaffolding is used to overcome the weaknesses of the inquiry learning model. This study was aimed to determine the effect of learning inquiry learning model accompanied with scaffolding towards the students' cognitive learning outcomes on Biology subjects in Special Region of Yogyakarta Mountain Areas. This research is a quasi-experimental research. The data collection was collected from the result of learning test on digestive system material consisting of 20 multiple choice items. The total population is 267 students whereas the total sample is 114 students of public school in Special Region of Yoyakarta mountain areas. The sample selection used cluster random sampling method by taking four classes from nine classes which was divided into experimental classes and control classes. The data obtained were then tested using descriptive and inferential statistics.T-test that has previously been tested for nomality and homogeneity test was used for the test. The calculation of $t$-test obtained Sig value. (2-tailed) $<0,050$ so $\mathrm{H}_{0}$ is rejected and $H_{1}$ is accepted. This shows that there is a significant influence on the application of inquiry learning model with scaffolding on students' learning outcomes on digestion system material in Biology subject. Based on the result of the study, it can be concluded that the inquiry learning model with scaffolding can improve students' learning outcomes on the digestive system material in Biology subjects. It represents that there is a significant influence on the application of inquiry learning model with scaffolding on the students' learning outcomes in Biology subject.
\end{abstract}

Keywords-inquiry learningn model with scaffolding, biology learning outcomes, mountain areas

\section{INTRODUCTION}

The development of science and technology in the modern era has encouraged the improvement of the education quality. The quality improvement is done by the breakthrough of ideas that has implications on the changing of knowledge, skill, and technology [25]. Knowledge process which is relevant, responsive, and critical thinking are the demands of education in the $21^{\text {st }}$ Century [38]. In the $21^{\text {st }}$ century, science is increasingly intertwined so that the combination of science is growing. Science can develop in areas such as education, curriculum, and research [20]. Developing science encourages active participation and changes the way students learn.

Activities that emphasize active participation of students are more focus on the aspect of the investigation. All this time, Biology learning is still less emphasis on the scientific activities and still tend to knowledge transfer [13]. Based on the observations that have been done in the mountain area schools in Special Region of Yogyakarta (DIY), the learning process in the classroom tends to focus on the teachers and the students are still passive while the learning is going on, so that it resulted students' learning outcomes that have not been optimal. That kind of learning may limit the development of students' thoughts. Besides, the teacher still can not develop the cognitive aspect optimally. Average cognitive achievement of students in mountain area schools is 50,7 in Biology subjects. The efforts to improve students' Biology learning to improve students' cognitive can be done by investigation activities.

Investigation is an activity that emphasizes scientific activity by using instruments for data collection, making decisions about the presentation of data used, and determining the relationship between variables [26]. Biology learning is closely related to investigation activities which refer to scientific activities such as observing, questioning, hypothesizing, analyzing data and developing 
scientific knowledge, in addition, through investigation activities students can learn through a fundamental process [22]; [7]. One of the models that can accomodate students in scientific activities is the inquiry learning model [32]. The inquiry learning model matches the Biology learning characteristics and instructional needs of the students' active participation [41]. Through the inquiry model, students can develop a scientific way of thinking that enables students to understand a problem and gain answers in solving problems [26].

The inquiry learning model basically can train the students to integrate each of the inquiry stages used as the basis for the conclusion [29]. There are six stages of inquiry learning model, they are: (1) observe and learn stuff; (2) formulate inquiry question; (3) develop hypothesis; (4) design and conduct investigation; (5) analyze data; (6) argue [10]. In the Biology learning domain, learning activities using inquiry learning model can find data empirically through investigation [40].

The implementation of inquiry learning model in learning activities has several weaknesses and advantages. The advantages of this model are balancing three aspects such as cognitive, psychomotor, and affective aspects; besides, it can serve the need of the students who have high academic ability and are not hampered by students who have low academic. Not only having the advantages, this model also has some weaknesses, one of them is that it is still difficult to implement it in the class, so that it impacts on under academic students who less able to follow [15]. This model also lacks of control in large classes [12]. This makes the inquiry learning model requires an aid. The aid needed is the scaffolding.

Scaffolding is the teachers' assistance which is adapted to the student's abilities and the assistance is removed when the students can be self-responsible [28]. Scaffolding is used to complete the lack of inquiry learning model because basically not all students can implement inquiry learning model. Scaffolding is used to complete the inquiry learning model by inserting scaffolding steps into the inquiry learning model stage. The efforts of the combination are used to improve students' learning outcomes on Biology subjects of digestive system material. Research on inquiry learning model with scaffolding that can improve students' learning outcomes has been done by Quintana., et al (2004) [9] which states that inquiry learning model with scaffolding is an important element in cognitive aspect.

Learning outcomes refer to something that can be understood, known, and performed by the students after getting a learning process [1]. There are three aspects of learning results according to Benjamin Bloom, they are the cognitive domains, the affective domains, and the psychomotor domains [31]. This research will only focus on the cognitive learning outcomes. Cognitive learning outcomes refer to Bloom's cognitive domains such as remembering, understanding, applying, analyzing, judging, and creating [24]. Learning outcomes are basically influenced by environmental factors. The learning environment is generally in the form of social, psychological, and pedagogical environment. Learning environment can be called as effective environment when it provides favorable conditions in teaching and learning activities [17]. The condition of learning environment such as school environmental condition is influenced by geography factor like mountain area. This is because an area can be a community opportunity in enjoying educational facilities and forming potential students [30]. The mountain areas used as the focus of this research are areas in the Merapi mountain and Menoreh mountain in the Special Region of Yogyakarta. Based on the background of the problem, it would be conducted a research on the effect of inquiry learning model with scaffolding on the learning outcomes in mountain areas in the Special Region of Yogyakarta (DIY).

\section{RESEARCH METHODOLOGY}

This study is a quasi-experimental research which was aimed to find out the influence of inquiry learning model with scaffolding on the students' learning outcomes on the Biology subject materials. This research was conducted in Merapi mountain area and Menoreh mountain area in the Special Region of Yogyakarta (DIY). The population was taken from public high schools in those mountain areas which includes 267 students and the sample was used 114 students. Schools which were used as the sample are SMA Negeri 1 Pakem, Sleman District, Merapi mountain area and SMA Negeri 1 Kalibawang, Kulon Progo District, Menoreh mountain area. Basically, the population shows the overall object of the research that has certain characteristics to be studied [39].

The sample selection used cluster random sampling method by taking experimental class and control class. Selection of this sample is a group sampling with the units selected are not individuals but groups [11]. The classes used in this study consist of experimental class and control class. The experimental classes are class XI MIPA 3 in SMA Negeri 1 Pakem and class XI IPA 2 in SMA Negeri 1 Kalibawang, while the control classes are class XI MIPA 2 in SMA Negeri 1 Pakem and class XI IPA 1 in SMA Negeri 1 Kalibawang. The variable in this research consists of two variables, they are independent variable and dependent variable. The independent variable is the inquiry learning model with scaffolding, while the dependent variable is the outcomes of students' learning.

The data obtained are then tested with the descriptive and inferential statistics. Descriptive statistics are used to provide descriptive descriptions of data collected in the study [3], whereas inferential statistics are used in drawing inferences from sample to population [18]. The test used in this study used a 
t-test test that had previously been tested for normality and homogeneity using SPSS 24. Normality test was done to find out the distribution of sample data to be analyzed normal or abnormal using Shapiro-Wilk test with significance value > 0,050, while homogenity test using Levene test with significance value $>0,050$. After normality test and homogeneity test, then the whole data is tested by using t-test on the experimental group and control group. The basis of the decision making is by looking $\mathrm{t}$ count $>\mathrm{t}$ table and the acquisition of significance value (2-tailed) <0,050 with hypothesis testing are: (1) $\mathrm{H}_{0}$ : There is no significant difference between learning outcomes in experimental class and control class; (2) $\mathrm{H}_{1}$ : There is a significant difference between the learning outcomes of the experimental class and the control class.

The technique of collecting data was done by observation, documentation, and cognitive test in the form of multiple choice questions consisting of 20 items about the digestive system learning material. The research steps began with pretest on digestive system material, followed by the application of inquiry learning model with scaffolding in teaching and learning activity. After the model of inquiry learning with scaffolding applied, the next step was post test on the same problem about the digestive system material. The collected data is then analyzed using the application of SPSS 24.

\section{RESULT}

Description of data of influence of inquiry learning model with scaffolding on students' cognitive learning outcomes on food digestion system material.

TABLE I. PRETEST AND POSTTEST RESULT OF EXPERIMENTAL CLASSES AND CONTROL CLASSES

\begin{tabular}{cccc}
\hline \multirow{2}{*}{ Class } & Total & Pretest & Posttest \\
\cline { 3 - 4 } & & Average & Average \\
\hline Experimental & 57 & 57,5 & 72,4 \\
\hline Control & 57 & 54 & 58,5 \\
\hline
\end{tabular}

The results of pretest and posttes in the experimental class and control class are then tested in normality and homogeneity test. Normality test using Shapiro-Wilk test with significance level of 0,050 in experimental classes and control classes. The tested data are the pretest and posttest test result on the digestive system material. Pretest and posttest normality test data are presented in TABLE II.
TABLE II. PRETEST AND POSTTEST OF NORMALITY TEST

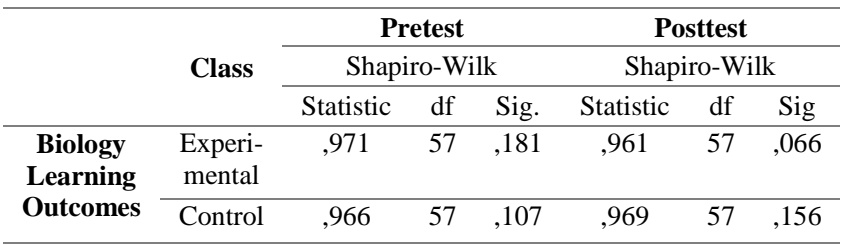

Based on the normality test data, it can be concluded that pretest and posttest data is classified into normal because the value of significance is > 0,05 . The value of significance in the experimental classes in pretest shows the result of $0.181>0.050$, whereas in the posttest the result is $0.066>0.050$. The significance value in the control class on pretest shows a significance value of $0.107>0.05$, whereas in the posttest, it shows a significance value of 0.156 $>0.050$. Furthermore, the homogeneity test is done to find out the homogeneous data already obtained.

Homogeneity test was used to find out the distribution of the data whether it is homogeneous or not. Homogeneity test used was Levene test with the level of significance is 0,050 in experimental classes and control classes. The results of pretest and posttest data calculations show that the data used is homogeneous. Homogeneous data is presented in TABLE III.

TABLE III. PRETEST AND POSTTEST RESULT OF HOMOGENITY TEST

\begin{tabular}{cccccc}
\hline & & \multicolumn{4}{c}{ Test of Homogenity of } \\
& Treatment & \multicolumn{4}{c}{ Variance } \\
\cline { 3 - 6 } & & $\begin{array}{c}\text { Levene } \\
\text { Statistic }\end{array}$ & df1 & df2 & Sig. \\
\hline $\begin{array}{c}\text { Biology } \\
\text { Learning } \\
\text { Outcomes }\end{array}$ & Pretest &, 123 & 1 & 112 &, 726 \\
\cline { 2 - 6 } & Posttest & 3,114 & 1 & 112 &, 080 \\
\hline
\end{tabular}

Based on the homogeneity test it was found that the data used are homogeneous because the significance value is $>0,050$. Homogeneity on pretest shows a value of $0.726>0.050$ and prettest shows a value of $0.080>0.050$. After the data used are stated normal and homogeneous, then the data was tested using $t$ test to see the effect of inquiry learning model with scaffolding on students' learning outcomes on digestive system material. The basic decision-making is declared influential when $\mathrm{t}$ count $>\mathrm{t}$ table and the significance value $(2$-tailed $)<0.050$. The data of $t$-test result are presented in TABLE IV. 
TABLE IV. T-TEST TEST

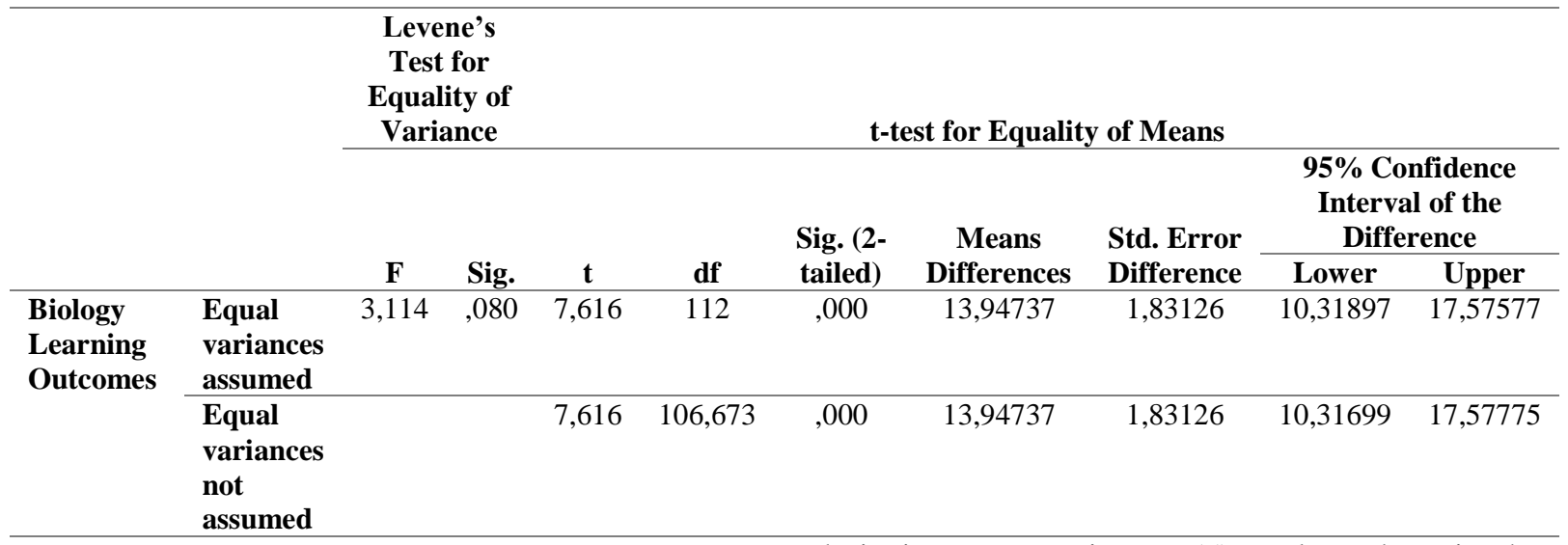

The result of t-test shows that the inquiry learning model with scaffolding has a significant influence on the students' learning outcomes in Biology subject's materials. This is shown on t count $>\mathrm{t}$ table with the acquisition of $7.616>1.65833 . \mathrm{t}$ count was obtained from the calculation using t-test with SPSS 24 application, while t table was obtained from table $\mathrm{t}$ distribution with the number $\mathrm{n}=114$ that is equal to 1.67203 .

\section{DISCUSSION}

The inquiry learning model is a model that gives students a scientific problem and then it has to be resolved through inquiry stages [8]. This model is used to accommodate the activity of 'finding out' through the investigation from the scientific questions they get [35]. There are six stages of inquiry learning model used in this research, they are: (1) observe and learn stuff, in the form of observing activities and students can identify problems; (2) formulate inquiry question, in the form of formulating the problem stage; (3) develop hypothesis, in the form of a temporary answer-making stage; (4) design and conduct investigation, in the form of stage of designing an experiment; (5) analyze data, in the form of stage of analyzing experiment result data; (6) argue, in the form of stage of presenting experimental data which has already done [10].

The inquiry learning model is not optimally applied to the classroom. Efforts to optimize the application of inquiry learning model need an assistance. The assistance is scaffolding. Scaffolding is used to support students in achieving learning objectives by providing assistance from adults adapted to the child's abilities and then the assistance will be released as the child can be self-responsible [19]; [28]. Scaffolding in this research has three stages: (1) environmental provisions which is in in the form of introduction stage; (2) explaning, reviewing and restructuring which are in the form of stages of explaining, reviewing and restructuring; and (3) developing conceptual thinking which is in the form of conceptual thinking of students [36]. Merging between inquiry learning model with scaffolding is by inserting scaffolding steps into the steps of inquiry learning model. The scheme of the combination process of the learning inquiry model with the scaffolding steps is presented in Fig. 1.

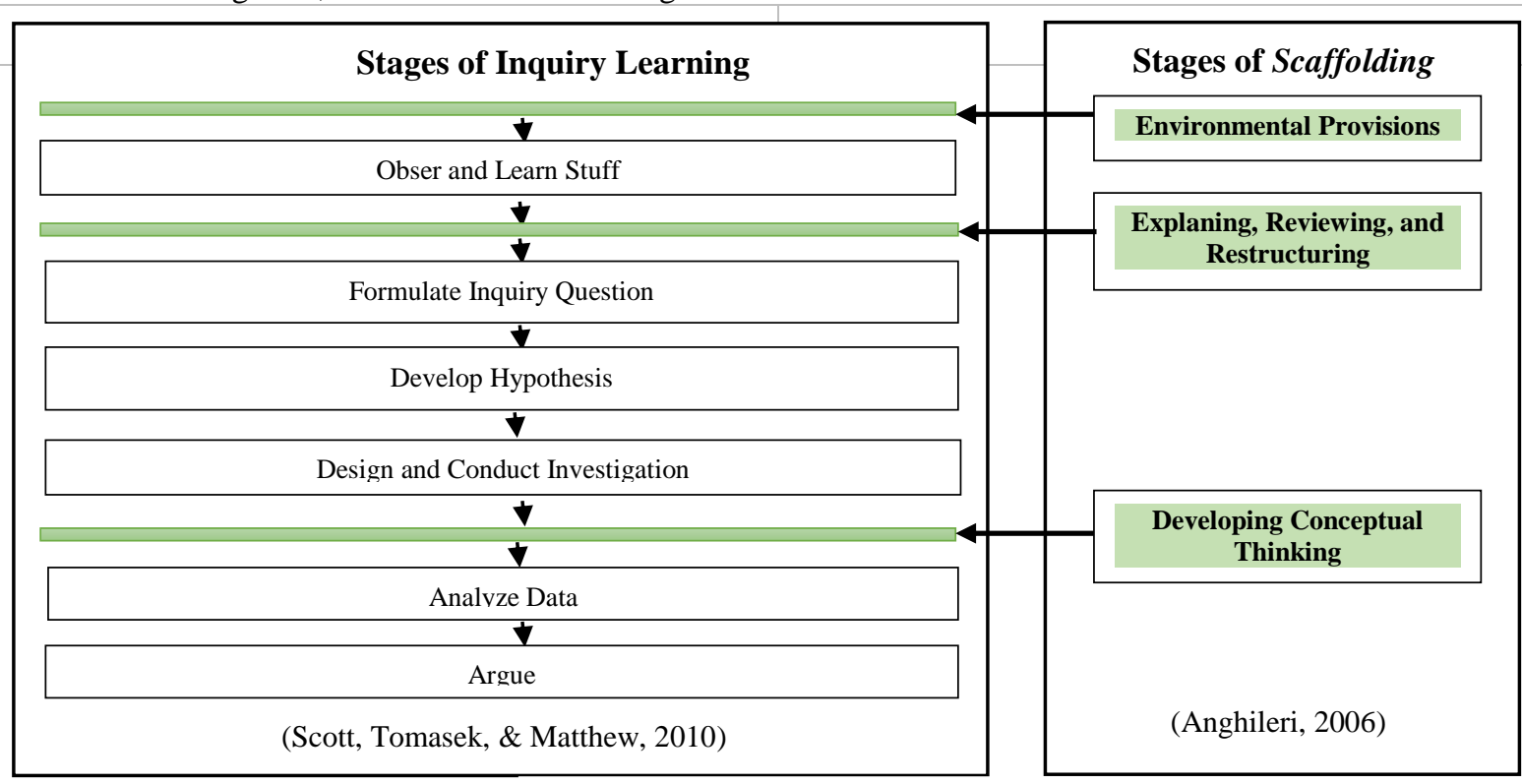

Fig 1 . The scheme of inquiry learning model with scaffolding 
The combination of inquiry learning model with scaffolding presented in Fig. 1 has the potential to improve student learning outcomes. Insertions of the scaffolding stages are environmental provisions stage inserted before obser and learn stuff; explaning, reviewing, and restructuring stages inserted before formulate inquiry question; and the stage of developing conceptual thinking inserted before analyze data. The implementation of learning activities that apply inquiry learning model with scaffolding used Student Worksheet (LKS). LKS on inquiry learning model refers to the material of the digestive system, while scaffolding refers to a problem that is a trend among high school students that is PCC. Scaffolding is used only as an aid so that students do not have difficulties on using the inquiry learning model in the classroom. Inquiry learning model with scaffolding has the potential to improve students' learning outcomes. This is shown in the results of the calculations using t-test with SPSS 24.

The description of data presented in this study was obtained from the daily test results on digestive system material of Biology subjects. This study consists of two classes, consisting of experimental classes and control classes. The first stage in the experimental and control classes were treated the same with the pretest. Pretest was used to determine the similarity of the capability of the control classes and experimental classes. After that, it was conducted a research in the experimental classes with the application of inquiry learning model with scaffolding while in the control classes were not given the inquiry learning model with scaffolding. At the end of the meeting, the two classes were given the same treatment that is with the posttest. Basically the model of inquiry learning with scaffolding facilitate the teacher In guiding the application of inquiry learning model [28]. Scaffolding also identifies the theoretical principles of intersubjectivity, contingent support, and the release of responsibility [19]. Scaffolding has advantages in improving students' accuracy [37]. Basically the application of scaffolding in the inquiry learning model is an aid for novice students in building aspects of knowledge [33].

Based on the results of the above analysis of inquiry learning model with scaffolding is appropriate to be used to improve students' learning outcomes on the cognitive aspects. In this regard Abadikhah \& Valipour (2018) [37] say cognitive development is an activity that involves interaction between humans. Basically the inquiry learning model with scaffolding is able to accommodate students in scientific activities, so that students can interpret data and draw conclusions [21]. Application of inquiry learning model assisted with scaffolding becomes a strategy in direct instruction in learning. Direct instruction is provided according to students' need [8]. The inquiry learning model with scaffolding becomes the combination needed in the learning activities in the classroom [28]. The effort of combining inquiry learning model with scaffolding is used to improve students' learning outcomes on digestive system material in Biology subject.

The learning outcomes which was used in this study refers to the learning outcomes of cognitive learning in Biology subjects. Biology concept was obtained independently from the phenomenon possessed. The material of the digestive system is a material that can be used to carry out investigative activities because the material is designed based on constructivist learning [2]. In line with Berat, Nowak, et al. (2013) [21] states that through the process of investigation on Biology learning may affect the students' ability and may consider cognitive and behavioral skills. Controlled behavior depends on one's performance [27]. Learning outcomes are fundamentally influenced by environmental factors such as family environment, school environment, relationships between students and culture [23]. In addition parents factors also play a role in the development of students through the response and demands [4]. Not only influential parents factor, but also another factor that is the school environment factor. A more conducive school environment can contribute to a positive student experience so that learning is more effective [14]. The environmental conditions are influenced by geographic character. Geography can affect the mobility and educational outcomes in an area such as a mountainous area [30].

Special Region of Yogyakarta is surrounded by two large mountains, they are Merapi mountain and Menoreh mountain. The height of the mountains in the DIY area ranges from 100-499 $\mathrm{m} \mathrm{dpl}$ and 500$999 \mathrm{~m}$ dpl [34]. Communities in the mountain region of DIY are dominated by people working in agriculture, tourism, and animal husbandry [16]. Basically economic growth also has an effect on the quality of the environment [5]. This environmental conditions can affect students' condition at school especially in cognitive aspects. Parental involvement in this condition also plays a role because social relationships with parents are an important support for students' psychological which impact on students' achievement [6]. It can be known that environmental conditions are factors that affect students' learning outcomes. Learning outcomes refer to something that can be understood, known, and done by students [1].

Based on the results of the research that has been done, the results of the research on the influence of inquiry learning model with scaffolding on cognitive learning outcomes in Merapi and Menoreh mountain areas in Special Region of Yogyakarta shows a significant influence.

\section{CONCLUSION}

From this study, it can be concluded that there are differences of learning outcomes between experimental classes using inquiry learning model with scafolding with control class that does not use 
inquiry learning model with scaffolding. Calculations in this study using t-test. Before the t-test is done, normality and homogeneity test was tested first. The results of t-test calculations was gained from $\mathrm{t}$ count $>$ $\mathrm{t}$ table with the acquisition of $7.616>1.6583 . \mathrm{t}$ count obtained from the calculation using $t$-test while t table obtained from table $\mathrm{t}$ distribution with the number $\mathrm{n}=$ 114 that is equal to 1.6729 . The result of the t-test shows that $\mathrm{H}_{1}$ is accepted which states that there is a significant difference between the learning outcomes in the experimental classes and the control classes. This means that there is a significant difference between the experimental classes used the inquiry learning model with scaffolding and the untreated control classes. Learning outcomes are also influenced by several factors. One of them is environmental factors. Environmental conditions are influenced by the geography, like mountain areas. The mountain areas used in this study are the areas of Merapi mountain and Menoreh mountain in the Special Region of Yogyakarta.

\section{ACKNOWLEDGMENT}

The authors would like thank Mrs. Sri Budirahayu, Mr. Subardiyono, Mr. Jaka Mulyana, and public school students in mountainous areas of Merapi and Menoreh, Special Region of Yogyakarta.

\section{REFERENCES}

[1] A.A. Aziz., Yusof, K,M., and J.M. Yatim, "Evaluation on the Effectiveness of Learning Outcomes from Students' Perspectives". Procedia - Social and Behavioral Sciences, vol. 56, pp. 22-30, 2012.

[2] AHI, Berat, "Thinking About digestive System in Early Childhood: A comparative study about Biological Knowledge". Cogent Education, vol. 4. Pp. 1-16, 2017. http://dx.doi.org/10.1080/2331186X.2017.1278650.

[3] A. Ferdinand, "Structural Equation Modeling: dalam Penelitian Manajemen". (BP UNDIP, Semanrang). 2006.

[4] A. Kiadarbandsari., Z. Madon., H. Hamsan., and K. Mehdinezhad Nouri, "Role of Parenting Style and Parents' Education in Postive Youth Development of Adolescents," Pertanika J. Soc. Sci. \& Hum, vol. 24(4), pp. 1465-1480, 2016.

[5] A.R. Ridzuan., N.A. Ismail., A.F.C. Hamat., A.H.S. Nor., and E.M. Ahmed, "Does Equitable Income Distribution Influence Environmental Quality? Evidence from Developing Countries of ASEAN-4". Pertanika J. Soc. Sci. \& Hum, vol. 25(1), pp. 385-400, 2017.

[6] A. Thompson, Ross., and L. Ontai, "Striving to Do Well What Comes Naturally: Social Support, Developmental Psychopathology, and Social Policy". Development and Psychopathology, vol. 12, pp. 657-675, 2000.

[7] C. Gurt., and A. Tallada, "Problem Students Experience with Inquiry Processes in The Study of Enzyme Kinetics". Journal of Biological Education, pp. 1-8, 2017, http://dx.doi.org/10.1080/00219266.2017.1285801.

[8] C. Hmelo-Silver., R, Duncan., and C. Chinn, "Scaffolding and Achievement in Problem-Based and Inquiry Learning a Response to Kirscher, Sweller, and Clark (2006)," Educational Psychologist, vol. 42(2), pp. 99-107, 2007, DOI: $10.1080 / 00461520701263368$.

[9] C. Quintana., B. Reiser., E. Davis., J. Krajicik., Fretz., R. Duncam., E. Kyza., D. Edelson., E. Soloway, "A Scaffolding Design Framework for Software to Support Science Inquiry," The Journal of The Learning Science, vol. 13(3), pp. 337 336, 2004.
[10] C. Scott., T., Tomasek., and E. Matthew, "Thinking Like a Scientist. Science and Children," pp. 38-42, 2010.

[11] D. Ary, L. Jacobs., and A. Razavieh. "Penganatar Penelitian dalam Pendidikan" (Pustaka Pelajar, Yogyakarta), pp. 201203, 2007.

[12] E. Shedletzky., and M. Zion, "The Essence of Open Inquiry Teaching". International Journal of Science Education, vol. 16(1), pp. 23-38, 2005.

[13] E. Wijaya., D. Sudjimat., and A. Nyoto, "Transformasi Pendidikan Abad 21 Sebagai Tuntutan Pengembangan Sumber Daya Manusia di Era Global". Proseding Seminar Nasional Pendidikan Matematuka, vol. 1, 2016.

[14] G.M. Styn, "The Impact of School Context on the Construction of Female Mathematic Teachers' Professional Identity in a South African Primary School". Pertanika J. Soc. Sci. \& Hum, vol. 26(1), pp. 519-534, 2018.

[15] I. Belgin, "The Effects of Problem-Based learning Instruction on University Student's Performance and Conseptual and Quantitative Problem in Gas Concept". Eurasia Jurnal of Mathematic, Science \& Technology Education, vol. 5(2), 2009.

[16] I. Pratomo, "Klasifikasi Gunung Api Aktif Indonesia, Studi Kasus dari Beberapa Letusan Gunung Api dalam Sejarah," Jurnal Geologi Indonesia, vol. 1(4), pp. 209-227, 2006.

[17] J. Fan., and L. Zhang, "The Role of Learning Environments in Thinking Styles". Educational Psychology, vol. 34(2), pp. 252-268. 2014. http://dx.doi.org/10.1080/01443410.2013.817538.

[18] Jogiyanto, "Metodologi Penelitian Bisnis: Salah Kaprah dan Pengalaman-Pengalaman, Edisi Pertama," BPFE: Yogyakarta, 2010.

[19] K, Brownfield., and I. Wilkinson, "Examining the Impact of Scaffolding on Literacy Learning: A Critical Examination of Research and Guideline to Advance Inquiry". International Journal of Educational Research. Pp. 1-16. 2018. https://doi.org/10.1016/j.ijer.2018.01.004.

[20] Kemendikbud. Konsep Pendekatan Scientifc, Bahan Pelatihan. Jakarta: Kementrian Pendidikan dan Kebudayaan RI, 2013.

[21] K.H. Nowak., R.T. Nehring., and A. Upmeier zu Belzen, "Assesing Students Abilities in Processes of Scientific Inquiry in Biology Using a Paper-and-Pencil Test," Journal of Biological Education, vol. 47(2), pp. 182-188, 2013. doi:10.1080/00219266.2013.822747.

[22] K. Kremer., C. Specht., D. Urhahne., J. Mayer, "The relationship in Biology Between the Nature of Science and Scientific Inquiry," Journal of Biological Education, vol. 28(1), pp. $1-8, \quad 2013$. http://dx.doi.org/10.1080/00219266.2013.788541.

[23] L. Deng., L. Wang., and Y. Zaho, "How Creativity Was Affected by Environmental Factors and Individual Characteristics: A Cross-Cultural Comparasion Prespective". Creativity Research Journal, vol. 28(3), pp. 357-366, 2016. Doi: 10.1080/10400419.2016.1195615.

[24] L. W. Anderson, and D.R. Krathwohl, “A Txonomy for Learning Teaching and Assesment: a Revision of Bloom's Taxonomy of Education Objectives". (Addison Wesley Longman, Inc, New York, San Fransisko, Boston) 2001.

[25] M. Amadi, and P. Ememe, "Rethinking Higher Education Curriculum in Nigeria to Meet Global Challenges in The 21st Century". International Prespectives on Education and Society, vol. 21, pp. 459-483. Emerald Group Publishing Limited, 2014. https://doi.org/10.1108/S14793679(2013)0000021019.

[26] M. Glackin., and C. Harrison, "Budding Biology Teachers: Whate Have Botanical Gardens Got to Offer Inquiry Learning," Journal of Biological Education, pp. 1-11. 2018. DOI:10.1080/00219266.2017.1357648.

[27] M. Mahmud., and S.M. Yusof, "The Influence of Religiosity on Safety Behafior of Workers: A Proposed Framework," Pertanika J. Soc. Sci. \& Hum, vol. 26(1), pp. 1-20, 2018. 
[28] M. Van Uum., R. Verhoeff., and M. Peeters, "Inquiry-Based Science Education: Scaffolding Pupil' Self-Directed Learning in Open Inquiry". International Journal of Science Educational, 2017. https://doi.org/10.1080/09500693.2017.1388940.

[29] M. Zion., and Sadeh, Irit, "Dynamic Open Inquiry Performances of High-School Biology Students". Eurasia Journal of Mathematics, Science and Technology, vol. 6(3), pp. 199-21, 2010.

[30] N. Hillman, "Geography of College Opportunity: The Case of Education Deserts," American Educational Research Journal, vol. 53(4) $\quad$ 987-1021, DOI:10.3102/0002831216653204.

[31] N. Sudjana, "Penilaian Hasil Proses Belajar Mengajar". PT Remaja Rosdakarya: Bandung, 2010.

[32] Perarturan Menteri Pendidikan dan Kebudayaan. Nomor 22 Tahun 2016 tentang Standar Proeses Pendidikan Dasar dan Menengah. Jakarta. 2016.

[33] P. Krischner., and G. Erkens, "Cognitive Tools and Mindtools For Collaborative Learning," J. Educational Computing Research, vol. 35(2), pp. 199-209, 2006.

[34] Rencana Kerja Pembangunan Daerah (RKPD) Daerah istimewa Yogyakarta Tahun 2016. Pemerintah Daerah Daerah Istimewa Yogyakarta, 2015.
[35] R. Hartono, "Ragam Model Mengajar yang Mudah Diterima Murid," DIVA Press: Yogyakarta, 2013.

[36] R.I. Anghileri. "Scaffolding Practices That Enhance Matematics Learning". Journal of Mathematics Teacher Education, vol. 9, pp. 33-52. 2006.

[37] S. Abadikhah, and M. Valipour, "The Effect of SelfTranscription and Expert Scaffolding on the Accuracy of Oral Production of EFL Learners". Pertanika J.Soc.\&Hum, vol. 26(1), pp. 149-166, 2018.

[38] S. Madson., and B. Cook, "Transformative Learning: UAE, Women, and Higher Education," Journal of Global Responsibility, vol. 1(1), pp. 127-148, 2010.

[39] Sugiyono, "Metode Penelitian Kuantitatif, Kualitatif, dan R\&D," Alfabeta: Bandung, 2011.

[40] T. Bell., D. Urhahne., S. Schanze., and R. Ploetzner, "Collaborative Inquiry Learning: Models, Tools, and Challenges". International Journal of Science Education, vol. 32(3), $\quad$ pp: $349-377, \quad 2010$. http://dx.doi.org/10.1080709500690802582241.

[41] T. Eysink., L. Gresen., and H. Gijlers. "Inquiry Learning for Gifted Childern”. High Ability Studies, vol. 26(1), pp. 63-74. 2015. http://dx.doi.org/10.1080/13598139.2015.1038379. 